\title{
THE USE OF PERFORMATIVE VERBS IN ARABIC
}

\author{
Ass. Lect. Mohammed Nasser \\ Department of English \\ University of Wassit
}

\section{Abstract}

Performative verbs are the verbs that are used along with the act identified in the sentence. In Arabic, performative verbs are often stated explicitly, namely in context-based sentences. In a few cases, the verb as well as the utterance has a locutionary force, i.e., both contribute to the meaning of the sentence. The use of the performative verbs is significant in reported sentences, as certain sentences can have a different meaning if these sentences are uttered in direct speech.

\section{THE EXPLICIT USE OF PERFORMATIVE VERBS}

In Arabic, performative verbs are explicitly stated. These occasions involve situations like marriage, business contracting and the like.

Other situations that are non-formulaic are religious or ritual-based announcements; the announcements that are made upon the fulfilment of highly ritualized acts like prayer (Nelsen 1996: 113 and Johansson 2004: 244). Performative verbs are commonly used in legal transactions, including marriage, court declarations, and official contracting. The declarations uttered in a marriage ceremony begin with phrases like :

1قبلت الزواج منانك

I agree that I marry you.

( lit. I accepted the marriage with you )

( Kharma and Mitchell $1985: 112$ ).

A declaration like this is pronounced in the same time the marriage ceremony takes place. The person involved is not only performing an act, that is marriage, but he / she is also pronouncing an utterance during that performance. The same is true in the act of divorce; either consort, namely the husband, often utters these words :

طلقتاك ثلاث

I pronounce you divorced.

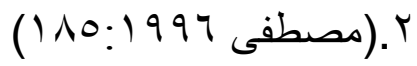

( lit. I divorced you three times ).

In business contracting, performative verbs are used too and roughly with the same tense used in marriage or divorce, that is the past tense. The seller, while dealing with the buyer, utters the following :

بعتلك هذا

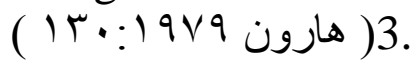

I sell you this.

( lit. I sold you this ).

The speaker here, represented by a seller, is performing a business act and is uttering words relevant to the context related. If for any reason, the business act is cancelled or is not accomplished,as the selling in progress, the 
seller will not utter these words. This is since the utterance needs to be simultaneous with the performance of the act. In judicial and official declarations, there are common utterances permanently encountered in setting described as such. e.g.

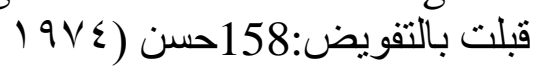

I hereby accept the authorization.

( lit. I accepted the authorization entitled to me ). and

اشهد بصحة ما اقول

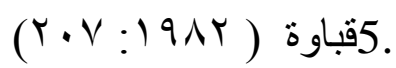

I certify that what I say is true.

( lit. I certify the righteousness of what I say ).

There are two aspects typical of the performative-based acts of the kind discussed above., viz. judicial and official declarations. The first aspect is that most of these declarations are written and not verbal declarations.This is seen in official and semiofficial transactions. Hence,

they are called

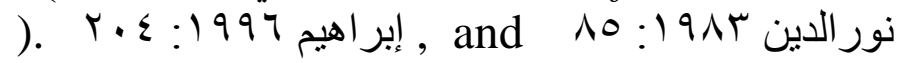

The other aspect is that the speaker here is sometimes made explicit.

In strictly formal declarations, the speaker is easily identified through the we. The identification انحن am and اني use of the first person pronouns; might include a description of that speaker too, as in :

$$
\text { إبر اهيم (TrY: }
$$

$I$, the undersigned.

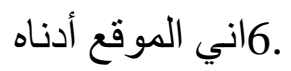

(lit. I am, who have signed down here ).

This will consequently lead to describe not only the speaker, but also the context involved, i.e., government office, business contract ,etc. In other words , the kind of the words uttered here can be useful in identifying the context or the situation in which these words are uttered.

Performative verbs are also used in religious contexts. Of these contexts are the verses of the Holy Qur'an:

$$
\text { أني أعضك ان تكون من الجاهلين "I }
$$$$
\text { “ }
$$

'I warn you not to be of the ignorant. '

$$
\text { Ali ( } 1989: 366 \text { ). }
$$

and :

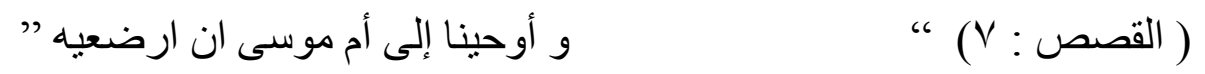

' We thereupon inspired into Mose's mother 'that you shall suckle him. ' (ibid. : 1210 ).

In prayer, performative verbs are used. These verbs are used either prior to prayer, that is when the person has prepared himself / herself to pray :

7. نويت الصلاة ويت ان اصلي

I intend to pray,

or during the prayer itself :

8 اشهُ ان لا اله الا اله

I certify that there is no god but Allah. 


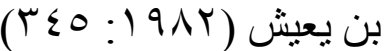

\section{ELLIPSIS AND REPETITION IN MEANING}

When performative verbs are not stated, these verbs are then replaced by the respective structures, according to the meaning the single sentence will, for example, can replace the السين denotes. The particles

to promise in : و عد the verb

9 9.

I will come tomorrow.

Beeston (1968: 130).

This sentence conveys a promise and it is therefore equivalent in meaning to :

10. اعد ان اتي غدا.

I promise I will come tomorrow. ( ibid. ).

A performative verb may as well replace a structure in that it serves the same function made by that structure. Some grammarians like

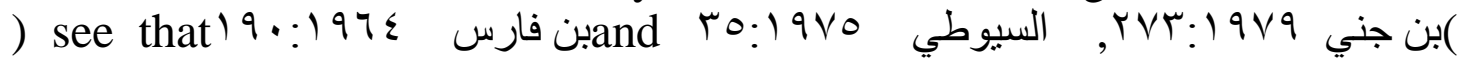
the omission the syntactic particles is not a rule. According to these grammarians, these particles can be used instead of verbs. The particle

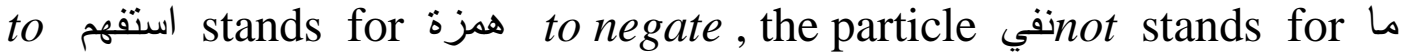
to join or relate, عطف and stands for ginquire, words such as to call. (ibid. ). It is not alsoينادي $O$ for and the vocative particle common to state both the particle and the verb in the same time. For instance , in vocative sentences, either the verb or the particle related is used, whereas both of them may not be used as in :

ادعوك يازيد

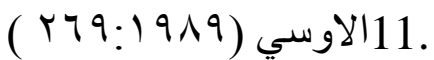

I call you, O Zeid!

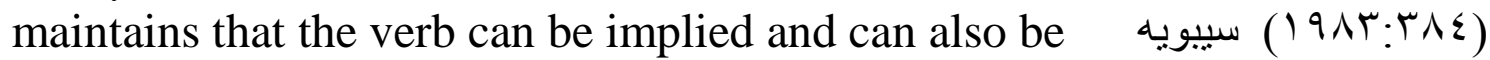
made explicit. This is possible elsewhere, in which case the performative verb is stated along with the perlocutionary act :

12. اشئ انك لرسول الله

I certify that you are verily the messenger of Allah.

In the Holy Qur'an :

"( القمر : (1)

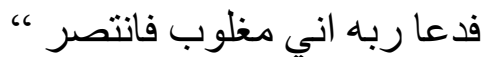

' He prayed into his Lord, I am vanquished, have support for me.'

Ali $(1989: 711)$.

\section{PERFORMATIVE VERBS IN INDIRECT SPEECH}

When sentences are transformed from direct to indirect speech, performative verbs are used, according to the meaning or context of the sentence. The sentences transformed undergo several changes ; not only the structure will be changed but the subject type., i.e., from first to second or third person. Of the other changes is the use of performative verbs. Such verbs are used when a sentence related denotes a belief, interpersonal reaction and the like ( Nelsen $1996: 220$ ).

The sentence, for example, $\mathrm{A}$ is different from the sentence B : 
13.A -

The man went.

and

14.B -

Be careful not to do that!

The man. In B , the الرجل In sentence A, there is a subject, that is subject is not as explicit as that in A. Sentence A denotes a commonplace activity ; something is done by someone, whereas sentence $\mathrm{B}$ has a meaning that is different from the one stated in A, viz, it implies a threat or the like. When a sentence like B is changed to indirect speech,

to forbid is هن هدر to threat or warn like accordingly used, which is dependent on the meaning of the sentence in question.Sentences in which the first person pronoun is used as a subject may undergo the same changes when transformed into indirect speech : 15. تبرأت عن ولائهم

I declare myself free from their affiliation.

Wright ( $1971: 106$ ).

أعلن When changed, this sentence will be introduced with verbs like to acknowledge. قاعترف to admit and to announce

Why don't you fight, townsmen! هلا تقاتلون أيها القوم Another example is حضضت القوم على القتال which is likely to be changed in indirect speech to exhortation.تحضيض urged townsmen to fight, for the sentence implies

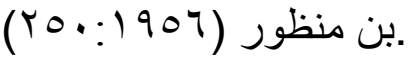

In public signs and slogans, performative verbs manifest a particular use. In other words, the performative verb fills the gap caused by the use of short phrases due to the context in which phrases like these are used, as in the case of prohibitives :

16.

DIVING PROHIBITED!

Tradd ( $1998: 133$ ).

and

17.

PASSAGE OF HIGH TRUCKS PROHIBITED !

Ghazali ( $2002: 170$ ).

\section{CONCLUSIONS}

1. A performative verb, when used in a sentence, is occasionally preceded by the first person pronoun, singular or plural.

2. Most performative verbs used in Arabic are stative perceptual verbs.

3. The use of performative verbs in Arabic is not peculiar to legal language. These verbs are also used in Qur'anic verses and religious rites.

4.Most performative verbs in Arabic are used in the past tense, especially in legal contracts.

The man went 5ذب الرجل Sentences or statements of the type 
have no overt meaning in general. Yet, these might also imply other different meanings, such as an indication for the hearer or the listener to stay or leave or a sort of promise or warning for that hearer or listener. Such sentences can be looked upon as indirect speech acts.

$D o$ ! 6. 6. The subject , ( the addressee ), in most directives , as in is not stated, but it is recoverable from the context, and therefore it is . أنinterpreted as

7. Some written prohibitions in Arabic are also correspondent in meaning to those based on no-phrases in English, NO DIVING! and NO HIGH TRUCKS !

\section{References}

\section{English References}

Ali , Y. ( 1989 ). Holy Qur'an : Text Translation and Commentary. Kuwait : That-es-Salasil Press.

Beeston , A. F. ( 1968 ). Written Arabic : An Approach to the Basic Structures. Cambridge : Cambridge University Press.

Ghazali , A. S. ( 2002 ). A Corpus - based Study on Some Scientific Vocabulary Items in Arabic. Maroc: Bibliothiqué National Marocain.

Johansson, M. L. ( 2004 ). Situated Sentences in English : A Working Paper in Spoken Discourse. Stockholm : Uppsala University.

Kharma, N. And Mitchell, T. ( 1985 ). A Contrastive Analysis of the Use of Verb Forms in English and Arabic. Heidelberg: Julius Groos Verlag.

Nelsen,D.( 1996 ). Linguistic Meaning and Function of Communication. Copenhagen : Language Academy Publishing.

Tradd , N. S. ( 1998 ). Travelwise Arabic : An International Guidebook for Foreigners. London : Barron Educational Series. 
Wright, W. ( 1971 ). A Grammar of the Arabic Language. 2 Vols. Cambridge : Cambridge University Press.

\section{Arabic References}

إبر اهيم ، سعيد. (1997 1). منهج النحو الوظيفي. تونس : مطبعة زياد.

الاوسي ، قيس إسماعيل ـ (919 (19). أساليب الطلب عند النحويين و البلاغيين. بذداد : جامعة بغداد. السيوطي ، عبد الرحمن. (9V0). شرح شو اهد المغني. ج جَ. بيروت : دار الحياة. المخزومي ، مهاي. (ع 97 (). في النحو العربي : نقدو توجيه. بيروت : دار صادر. بن جني ، أبي الفتح عثمان. (9V9 (1). الخصائص. ج جا. بيروت : دار الحياة.

بن فارس ، احمد. ( ؟ ؟ 19 ) ). ألصاحبى في فقه اللغة و سنن العرب في كلامها. تحقيق مصطفى الثويمي.

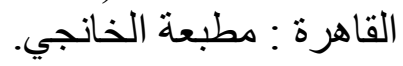
بن منظور، احمد. (907 1). لسان العرب. ج 1'ا. بيروت : دار صادر.

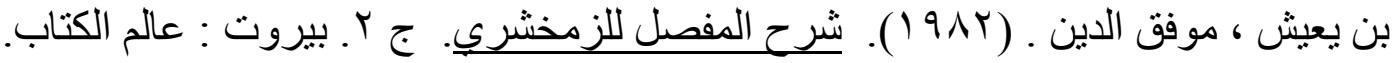
حسن ، عباس. (ع 19V1). النحو الو افي . ج 7. القاهرة : دار المعارف. سييويه ، عمرو بن عثمان. (س4 (19)). الكتاب. تحقيق عبد السلام محمد هارون. ج ؛ ـ بيروت : عالم

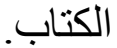

قباوة ، فؤاد. (r (191). تصريف الأفعال. بيروت : دار العلم للملايين. مصطفى ، إبر اهيم. (9V7 (). ا احياء النحو. القاهرة : المطبعة المنيرية. نور الدين ، عصام. (r/9 1). الزمن و الفعل. بيروت : المؤسسة الجامعية. هارون ، عبد السلام محمد. (9V9 (1). الأساليب الإنشائية في النحو العربي. القاهرة : مطبعة النحاس. 